\title{
Predicting ratoon rice growth rhythm based on NDVI at key growth stages of main rice
}

\author{
Kai-lou Liu', Ya-zhen $\mathrm{Li}^{1 *}$, Hui-wen $\mathrm{Hu}^{1}$
}

The growth of ratoon rice (Oryza sativa L.) is affected by growth of main rice, so it could be evaluated by determining growing condition of main rice. Objective of the study was to find regression model for predicting ratoon rice growth rhythm through establishing the quantitative relationship between growth rhythm in ratoon rice and normalized difference vegetation index (NDVI) after heading of main rice. NDVI at key growth stages of main rice was measured using active spectrometry for 12 varieties in 2008 and for 23 varieties in 2009, and compared the physiological indexes of main and ratoon rice. There was an exponential correlation $(P<0.05)$ between the NDVI after heading of the main rice and biomass, $\mathrm{N}$ concentration of green leaves and stems or leaf area index (LAI) after heading of the ratoon rice for all the 12 varieties in 2008. The regression models from the rice variety experiment in 2008 were used to calculate predicted values with NDVI after heading of main rice in 2009. The results showed that the predicted values of biomass, $\mathrm{N}$ uptake, and LAI in ratoon rice were significantly different to measured values. However, there were exponential and significantly positive correlation $(\mathrm{p}<0.05)$ between biomass and N uptake and LAI in ratoon rice and NDVI after heading of main rice in 2009. Therefore, it suggested that regression models were not perfect, and need to be improved adding more parameters about spectral characteristic of main and ratoon rice.

Key words: Canopy NDVI, exponential correlation, ratoon rice, regression equation.

\section{INTRODUCTION}

Ratoon rice (Oryza sativa L.) is a rice cropping system that has twice harvests in one season as it develops from dormant buds on the stubbles after main rice is harvested. It has been practiced in China since the West Jin dynasty (AD 265-316) (Guo, 1993) and latterly planted in India, Thailand, USA, and the Philippines (Nakano and Morita 2007). It is called twice harvesting rice in Japan (Nakano et al., 2008). The grain yield of ratoon rice is usually 1500 to $3000 \mathrm{~kg} \mathrm{ha}^{-1}$, being much lower than main rice. As ratoon rice has higher nutrient using efficiency per unit time and per unit land area than normal rice, many new varieties have been developed with high grain yield of ratoon rice and it is reported that yields of ratoon rice is as high as $8100 \mathrm{~kg} \mathrm{ha}^{-1}$ in Youxi county, Fujian Province of China (Xu et al., 2015; Lin et al., 2015).

In general, leaf area index (LAI) of ratoon rice was about one-eighth to one-fifth of that of main rice, and grain number per panicle and yield of ratoon rice were about one-third of those of main rice, while photosynthetic rate

${ }^{1}$ National Engineering and Technology Research Center for Red Soil Improvement, Jiangxi Institute of Red Soil, Nanchang 330046, China. "Corresponding author (liyazhen626@163.com).

Received: 16 October 2014.

Accepted: 29 June 2015.

doi: $10.4067 /$ S0718-58392015000500005 of ratoon rice was $20 \%$ to $70 \%$ higher than that of main rice in $10 \mathrm{~d}$ after full heading and net assimilation rate of ratoon rice was 3.7 to 6.0 times that of main rice from booting to maturity (Yi et al., 2009b). Many studies have been conducted to explore the reasons for the high yield of ratoon rice (Jiang et al., 2003; Zhang et al., 2005; Chen et al., 2008; Yi et al., 2009a). The grain yield of ratoon rice was affected by varieties, sowing time, cultivation method, fertilizer rate, and stubble height of main rice. Yi et al. (2009b) suggested varieties with more grains would achieve higher yield of ratoon rice. Zhang et al. (2005) found that the grain yield was higher when main rice was sowed earlier. Chen et al. (2008) indicated that the grain yield under super high-yield cultivation relied less on the photosynthate in the period of grain filling, which was beneficial to steady and high yield of ratoon rice. Jiang et al. (2003) suggested that the grain yield of ratoon rice had parabola correlation with $\mathrm{N}$ application for bud development. Xu et al. (2008) found appropriate amount of $\mathrm{N}$ application for bud development would be needed when ratoon rice was to be cultivated with varieties having spikelets per panicle of main rice. Harrell et al. (2009) indicate that when the initial stubble height is reduced from 40 to $20 \mathrm{~cm}$ the growth of the ratoon crop is altered by shifting panicle point of origin during the early growth period and delaying maturity. Yi et al. (2009a) suggested decline of the stubble height resulted in decreased number of effective panicles and increased 
grain number per panicle in ratoon rice. When ratoon rice is used as forage rice, to produce the highest total DM yield, Nakano and Morita (2008) suggest that the best time for first harvest is the full heading stage and the best $\mathrm{N}$ management is to provide $300 \mathrm{~kg} \mathrm{~N} \mathrm{ha}^{-1}$ in accordance with $33.3 \mathrm{~N}$ application at transplanting, $33.3 \%$ at the maximum tiller number stage, $16.7 \%$ at $7 \mathrm{~d}$ after the first harvest, and $16.7 \%$ at $21 \mathrm{~d}$ after the first harvest, respectively. And, the total estimated leaf and stem total digestible nutrient yields were higher in double harvesting than in single harvesting in most cultivars in Japan.

Spectral determination provides an automatic, quick, and nondestructive method of assessing crop biomass and nutrient status. The normalized difference vegetation index (NDVI) is an empirically derived index used to estimate plant biomass through the integration of the redvisible and near-infrared spectral regions to represent plant pigmentation and chlorophyll content respectively. NDVI is one of the most extensively applied vegetation indices related to leaf area index (LAI), biomass and predict yield (Raun et al., 2001; Ma et al., 2001; Inman et al., 2007; Gnyp et al., 2014). Wang et al. (2003) and Guo et al. (2008) found that there were significantly positive correlation between chemical contents and $\mathrm{N}$ nutrition of leaves and NDVI in rice and corn. Li et al. (2008) suggested that there was exponential function relationship between $\mathrm{N}$ absorption and NDVI in wheat. NDVI measurement has been applied to diagnose nutrient, particularly $\mathrm{N}$ status for the growth period development of many crops such as rice and wheat (Zhu et al., 2008), but it is never reported for predicting ratoon rice growth from main rice growth. Axillary buds and nutrient in stubble were important for growth and high yield of ratoon rice, because axillary buds in ratoon rice were affected by total content of internodes after heading of main rice. Total $\mathrm{N}$ content of internodes was the main factor to decide ratoon rate of axillary buds in early productive stages in main rice, but soluble sugar content in middle and late productive stages in main rice (Yi et al., 2005). Zheng et al. (2004) suggested that the development of axillary buds depends on the remnant root system of main rice, there was significantly positive correlation between panicle numbers and grain yield of ratoon rice and root system activity at mature stage of main rice. The activity of nitrate reductase, chlorophyll contents, and net photosynthetic rate in leaves of ratoon rice increased as $\mathrm{N}$ application rate was enhanced (Jiang et al., 2005). During the growth and development of the main rice, various starches and sugars are accumulated in leaves and culm of the plant which are subsequently translocated to the developing grain after flowering. The effect of characteristics of source-sink and flow of ratoon rice were closely related to stubble height of main rice. Decline of the stubble height resulted in decreased number of effective panicles and increased grain number per panicle in ratoon rice (Yi et al., 2009a). About 52\%-70\% assimilation production stored in stubble was distributed in ratoon rice (Liu et al., 2007), and most of them were distributed in the upper second and third nodes of ratoon rice. $\mathrm{Xu}$ et al. (2008) suggested that efficient rate of $\mathrm{N}$ application for promoting ratooning bud development could be better predicted using chlorophyll meter reading (SPAD value) of flag leaf at the full heading stage of main rice. These results showed that the grain yield of ratoon rice was affected by the growing condition in major growth stages from tillering to physiological maturity of main rice. Therefore, it is hypothesized that nutrient status at the key stages of main rice influence nutrient status at the key stages of ratoon rice irrespective of ratoon rice varieties and this will be reflected by NDVI. The objectives of this study were to establish the relationship of NDVI at the key stages of main rice with LAI, biomass, and $\mathrm{N}$ accumulation of key stages in ratoon rice by using a group of varieties, and to test and develop the model by different densities.

\section{MATERIALS AND METHODS}

Field experiments were conducted in 2008 and 2009 in Xiabao village's farm, Meixian town, Youxi County, Fujian Province ( $\left.26^{\circ} 10^{\prime} \mathrm{N}, 118^{\circ} 08^{\prime} \mathrm{E}\right)$, China, from March to mid-October. The soil was paddy soils as Anthrosols (IUSS Working Group WRB, 2014) with $\mathrm{pH} 5.5$, and alkali hydrolyzable $\mathrm{N}$ (AH-N) $160.4 \mathrm{mg} \mathrm{kg}^{-1}$, available P (AP) $34.2 \mathrm{~g} \mathrm{~kg}^{-1}$, and available $\mathrm{K}$ (AK) $41.5 \mathrm{~g} \mathrm{~kg}^{-1}$. The research area was representative of a typical sub-tropical moist climate with a mean annual temperature of about $19.2^{\circ} \mathrm{C}$, a maximum daily temperature higher than $35^{\circ} \mathrm{C}$ in summer and a rainfall of $1400-2000 \mathrm{~mm}$, about $50 \%$ of which falls from March to June, and this pattern was observed during the field experiment.

\section{Experimental design and crop management}

Experiment 1. Varieties of rice 'Tianyou 3301', 'Eryou 139', 'Eryouhang 2', 'Eryouhang 1', 'Eryou 6', 'Eryouming 86', 'Eryou 1273', 'Eryouming 118', 'Eryou 623', 'Eryouguang 810', 'Eryouhang 131', 'Shanyou 63' were offered by Fujian Academy of Agricultural Sciences in China. They were sowed on 17 March, and planted to a paddy field with a mean of 25 hills $\mathrm{m}^{-2}(20 \mathrm{~cm} \times 20$ $\mathrm{cm})$ on 15 April. Plots were separated by the clay $(40 \mathrm{~cm}$ over soil surface) and size was $40 \mathrm{~m}^{2}(8 \mathrm{~m} \times 5 \mathrm{~m})$. They were arranged in a randomized complete block with three replicates.

Experiment 2. 'Eryou 1273' was sowed on 17 March, and planted with a mean of 12.0, 16.5, 21.0, 25.5, 30.0, and 36.0 hills $\mathrm{m}^{-2}$ on 15 April. Plots were separated by the clay ( $40 \mathrm{~cm}$ over soil surface) and size was $40 \mathrm{~m}^{2}(8 \mathrm{~m} \times 5 \mathrm{~m})$ and were arranged in a randomized complete block with three replicates.

The experimental field was irrigated for land soaking, and plowed the saturated soil. All the plots were prepared 
under submerged condition (depth of water about $5 \mathrm{~cm}$ ) before planting. In main rice, a total amount of fertilizers urea, calcium magnesium phosphate, and potassium chloride were applied at rates of $288.0 \mathrm{~kg} \mathrm{~N} \mathrm{ha}^{-1}, 72.0 \mathrm{~kg}$ $\mathrm{P}_{2} \mathrm{O}_{5}$ ha $^{-1}$, and $144.0 \mathrm{~kg} \mathrm{~K}_{2} \mathrm{O}^{-1}$. Full $\mathrm{P}_{2} \mathrm{O}_{5}$ and $30 \%$ total $\mathrm{K}_{2} \mathrm{O}$ and $20 \%$ total $\mathrm{N}$ were added in soils by hand as basal fertilizer, $1 \mathrm{~d}$ before transplanting. Additional $\mathrm{N}$ and $\mathrm{K}_{2} \mathrm{O}$ was spread over at early tillering on 5-6 leaf age (30\% total $\mathrm{N})$, and that at booting stage on 12-13 leaf age (20\% total $\mathrm{N}$ and $35 \%$ total $\mathrm{K}_{2} \mathrm{O}$ ) and $14-15$ leaf age (20\% total $\mathrm{N}$ and $35 \%$ total $\mathrm{K}_{2} \mathrm{O}$ ), respectively. In ratoon rice, $\mathrm{N}$ was supplied as urea at a rate of $195 \mathrm{~kg} \mathrm{~N} \mathrm{ha}^{-1}$. Which was split as the budding fertilizer ( $80 \%$ of the twice total $\mathrm{N}$ ) on 15-20 d after full heading of main rice, on 1-2 d after harvesting of main rice as tillering fertilizer $(20 \%$ of the twice total $\mathrm{N}$ ).

Main rice was mowed by hand to a stubble height of $40 \mathrm{~cm}$ at the yellow ripe stage. Except for the chemical fertilizer application shown above, water, weeds, insects, and disease were controlled as required to avoid yield loss.

Canopy reflectance measurements and plant sampling Rice canopy reflectance measurements in the $780 \mathrm{~nm}$ near and $671 \mathrm{~nm}$ infrared wavebands (6 nm in width) were made using an optical sensor unit (GreenSeeker, NTech Industries, Ukiah, California, USA). The sensor was held above the rice canopy at a height of $45 \mathrm{~cm}$ from the top of the canopy, under cloudless conditions, and as close to solar noon as possible. The measurements in Experiments 1 and 2 were made at the tillering ( 7 May), booting (4 June), heading (9 July), and maturity stages (5 August) in main rice and heading (10 September) and maturity stages (7 October) in ratoon rice. Ten canopy spectral reflectance measurements were obtained in each plot, then averaged. NDVI is calculated as:

$$
N D V I=\frac{R_{N I R}-R_{R E D}}{R_{N I R}+R_{R E D}}
$$

where, NIR and RED are reflectances of near infrared and red channels, respectively.

Plants were sampled at all key stages in main and ratoon rice. In order to ensure representativeness of the sampling, we counted 50 hills from three different locations in each plot before sampling and recorded the tiller number for each hill. Then, based on the tiller number distribution of the 50 hills, three representative hills were reselected and destructively sampled. The samples were separated into green leaves, stems (including leaf sheaths), and panicles. The green leaf was measured with a leaf area meter (LI-3000, LICOR, Lincoln, Nebraska, USA) and expressed as LAI. All the plant parts were oven-dried at $80{ }^{\circ} \mathrm{C}$ to constant weight and weighed. And passed a $0.5 \mathrm{~mm}$ screen and digested by micro-Kjeldahl method. The digest was analyzed for $\mathrm{N}$ using semi-automatic Kjeldahl distillation apparatus and titration.

\section{Prediction with regression models}

The growing condition of ratoon rice was affected by main rice (Lin et al., 2007; Nakano and Morita, 2007; Yi et al., 2009b; Harrell et al., 2009), and the NDVI could be extensively related to LAI, biomass and predicted yield (Das et al., 1993; Raun et al., 2001; Ma et al., 2001; Inman et al., 2007). So, regression models were established by the relationship between canopy multispectral data of main rice and LAI, biomass and $\mathrm{N}$ accumulation of ratoon rice from Experiment 1.

Data from the rice field in Experiment 2 were subsequently used to validate the regression models. The validity of the models was estimated from the coefficients of determination $\left(\mathrm{R}^{2}\right)$, average relative error (ARE), root mean square error (RMSE), and index of agreement (d).

$$
\begin{gathered}
A R E=\frac{X_{O}-X_{S}}{X_{O} \times n}=100 \% \\
R M S E=\sqrt{\frac{\sum\left(X_{O}-X_{S}\right)^{2}}{n}} \\
d=\frac{1-\sum\left(X_{O}-X_{S}\right)^{2}}{\sum\left(\left|X_{S}-\bar{X}_{S}\right|+\left|X_{O}-\bar{X}_{O}\right|\right)^{2}}
\end{gathered}
$$

where, $X_{O}$ and $X_{S}$ are the measured and predicted values, respectively.

\section{Data analyses}

First, data were divided in two parts: before and after heading. And then, regression relationships between $\operatorname{NDVI}(\mathrm{X})$ and LAI, biomass and $\mathrm{N}$ accumulation (Y) in different key stages of main and ratoon rice were reestablished from the rice variety experiment in 2008 . Data of rice variety experiment in 2009 was to develop regression models.

\section{RESULTS}

\section{Comparison of grain yield between main and ratoon rice}

The grain yield of main rice was about $10000 \mathrm{~kg} \mathrm{ha}^{-1}$, and ratoon rice was $5000-7000 \mathrm{~kg} \mathrm{ha}^{-1}$ from the rice variety experiment in 2008 (Figure 1). There was a significantly positive correlation $(\mathrm{p}<0.05)$ between grain yield of main and ratoon rice irrespective of rice variety $\left(R^{2}=0.9712\right)$. The linear regression between main and ratoon rice was tested by the rice variety experiment in $2009\left(R^{2}=0.449\right.$, $\mathrm{p}<0.05$; Figure 2 ). The results showed that the grain yield of ratoon rice depend heavily on main rice. It suggested that the yield of ratoon rice was higher when the main rice was higher.

\section{Establishment of regression models}

The biomass and $\mathrm{N}$ content were different in all key stages both in main and ratoon rice, especially before and after heading period. So, data of NDVI, LAI, and biomass and $\mathrm{N}$ uptake was divided by heading period in main and ratoon rice. The period from tillering to heading was 


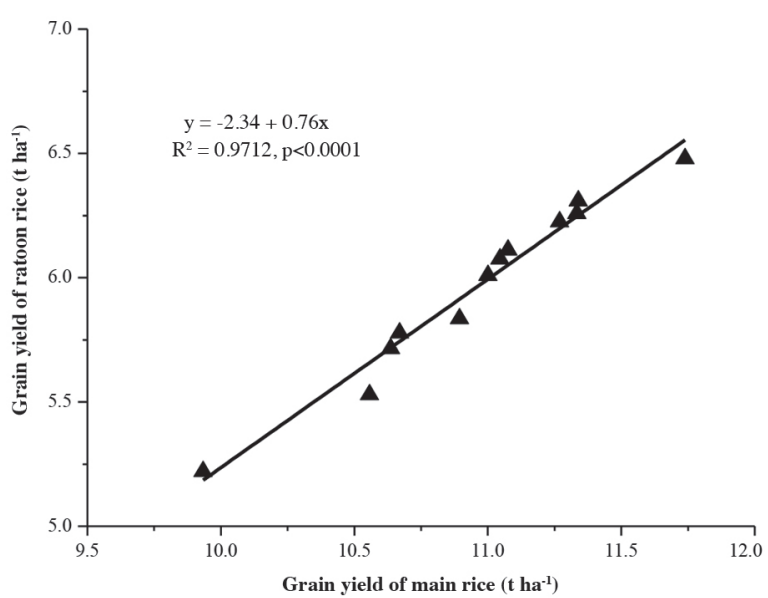

Figure 1. Relationships of grain yield between main and ratoon rice from the rice variety experiment in 2008.

before heading, and the period from heading to maturity was after heading.

NDVI was related to the biomass, LAI, and N uptake measured before and after heading period of main rice from the rice variety experiment in 2008 (Table $1)$, it showed that there were exponential and positive correlation significantly $(\mathrm{p}<0.05)$ between NDVI and biomass, $\mathrm{N}$ uptake of leaves and stem, $\mathrm{N}$ uptake of green leaves and LAI; $\mathrm{R}^{2}$ was $0.6781-0.9617$. These indicated the NDVI values before and after heading of main rice could better reflect changes of physiological indexes in this period, and predicted $\mathrm{N}$ uptake of leaves and stem, $\mathrm{N}$ uptake of green leaves, and LAI better than biomass.

To found the optimum NDVI of main rice which could reflect changes of physiological indexes of ratoon rice, the relationship between NDVI before and after heading of main rice and the biomass, LAI and $\mathrm{N}$ uptake measured after heading period of ratoon rice from the rice variety experiment in 2008 were analyzed (Table 2). It showed that there were exponential and significantly positive correlation $(\mathrm{p}<0.05)$ between biomass and $\mathrm{N}$ uptake and LAI in ratoon rice and NDVI after heading of main rice than before heading. These $\mathrm{R}^{2}$ were about $0.5831-0.6685$ and suggested that biomass and $\mathrm{N}$ uptake and LAI in

Table 1. Normalized difference vegetation index (NDVI) $(\mathrm{X})$ in correlation to the biomass and $\mathrm{N}$ uptake $(\mathrm{Y})$ measured after heading of main rice from the rice variety experiment in 2008.

\begin{tabular}{llcc}
\hline \multirow{2}{*}{$\begin{array}{l}\text { NDVI of main } \\
\text { rice }\end{array}$} & Different indexes of main rice & $\begin{array}{c}\text { Regression } \\
\text { equation }\end{array}$ & $\begin{array}{c}\text { Correlation } \\
\text { coefficient } \\
\left(R^{2}\right)\end{array}$ \\
\hline Before heading & Biomass of green leaves and stem & $\mathrm{y}=0.0487 \mathrm{e}^{5.082 \mathrm{x}}$ & $0.9617^{* *}$ \\
& Biomass of green leaves & $\mathrm{y}=0.0498 \mathrm{e}^{5.044 \mathrm{x}}$ & $0.9473^{* *}$ \\
& N of green leaves and stem & $\mathrm{y}=2.2687 \mathrm{e}^{4.417 \mathrm{x}}$ & $0.9309^{* *}$ \\
& N of green leaves & $\mathrm{y}=8.6823 \mathrm{e}^{-1.064 \mathrm{x}}$ & 0.3809 \\
& LAI & $\mathrm{y}=0.1244 \mathrm{e}^{4.4521 \mathrm{x}}$ & $0.9462^{* * *}$ \\
\multirow{5}{*}{ After heading } & Biomass of green leaves and stem & $\mathrm{y}=87.236 \mathrm{e}^{-2.552 x}$ & $0.7352^{*}$ \\
& Biomass of green leaves & $\mathrm{y}=0.2541 \mathrm{e}^{3.127 \mathrm{x}}$ & $0.6781^{*}$ \\
& N of green leaves and stem & $\mathrm{y}=0.3205 \mathrm{e}^{-0.817 \mathrm{x}}$ & 0.2916 \\
& N of green leaves & $\mathrm{y}=0.0010 \mathrm{e}^{5.568 \mathrm{x}}$ & $0.7043^{*}$ \\
& LAI & $\mathrm{y}=0.4121 \mathrm{e}^{3.654 \mathrm{x}}$ & $0.6992^{*}$ \\
\hline
\end{tabular}

LAI: Leaf area index.
Table 2. The exponential regression of normalized difference vegetation index (NDVI) (X) before and after heading of main rice to the physiological indexes (Y) after heading of ratoon rice from the rice variety experiment in 2008 .

\begin{tabular}{|c|c|c|c|}
\hline $\begin{array}{l}\text { NDVI of main } \\
\text { rice }\end{array}$ & $\begin{array}{c}\text { Different indexes of } \\
\text { main rice }\end{array}$ & $\begin{array}{l}\text { Regression } \\
\text { equation }\end{array}$ & $\begin{array}{c}\text { Correlation } \\
\text { coefficient } \\
\quad\left(R^{2}\right)\end{array}$ \\
\hline \multirow[t]{5}{*}{ Before heading } & $\begin{array}{l}\text { Biomass of green leaves, } \\
\text { stem and panicle }\end{array}$ & $\mathrm{y}=7.8885 \mathrm{e}^{0.541 \mathrm{x}}$ & $0.7246^{*}$ \\
\hline & Biomass of green leaves & $y=3.1889 e^{-3.253 x}$ & $0.8837^{*}$ \\
\hline & $\begin{array}{l}\mathrm{N} \text { uptake of green leaves, } \\
\text { stem and panicle }\end{array}$ & $y=0.1217 \mathrm{e}^{0.0718 \mathrm{x}}$ & 0.0275 \\
\hline & $\mathrm{N}$ uptake of green leaves & $y=0.1776 e^{-4.588 x}$ & $0.9370^{* *}$ \\
\hline & LAI & $\mathrm{y}=8.2054 \mathrm{e}^{-3.098 \mathrm{x}}$ & $0.9098^{* *}$ \\
\hline \multirow[t]{5}{*}{ After heading } & $\begin{array}{l}\text { Biomass of green leaves, } \\
\text { stem and panicle }\end{array}$ & $y=43.6850 e^{-1.966 x}$ & $0.6032 *$ \\
\hline & Biomass of green leaves & $y=0.0002 e^{11.269 x}$ & $0.6685^{*}$ \\
\hline & $\begin{array}{l}\mathrm{N} \text { uptake of green leaves, } \\
\text { stem and panicle }\end{array}$ & $y=0.1550 e^{-0.281 x}$ & 0.0266 \\
\hline & $\mathrm{N}$ uptake of green leaves & $\mathrm{y}=3 \mathrm{E}-07 \mathrm{e}^{15.179 \mathrm{x}}$ & $0.6465^{*}$ \\
\hline & LAI & $y=0.0012 e^{9.878 x}$ & $0.5831^{*}$ \\
\hline
\end{tabular}

LAI: Leaf area index.

ratoon rice were diagnosed by NDVI values after heading of main rice.

\section{The verification of regression models}

In experiment 2, errors were little between measured and predicted values of biomass of green leaves, $\mathrm{N}$ uptake of vegetative organs and green leaves and LAI (Figure 2). It was better when RMSE was 0.25 , so $\mathrm{N}$ uptake of vegetation parts and green leaves were predicted better by models (Table 3 ). And d values of these indexes were more than 0.94 (Table 3), so the models were all used

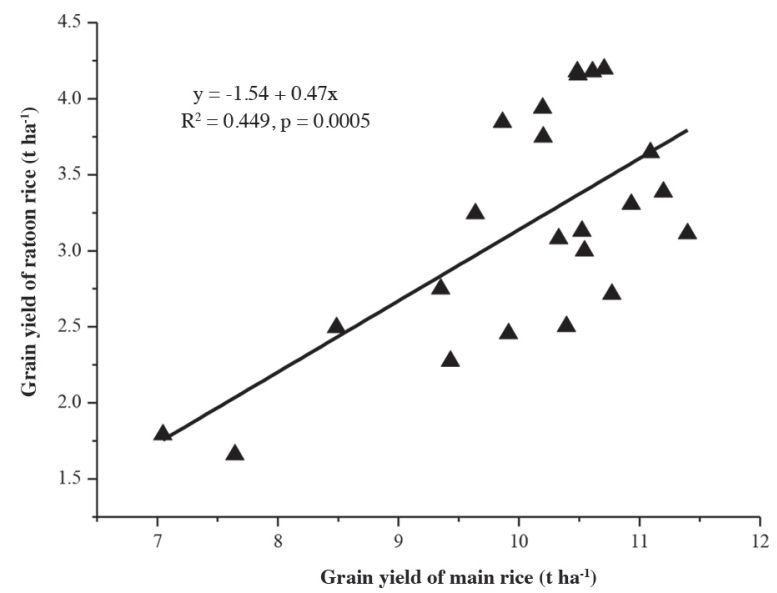

Figure 2. Relationships of grain yield between main and ratoon rice from the rice variety experiment in 2009.

Table 3. Errors of the correlations between the physiological indices of ratoon rice and normalized difference vegetation index (NDVI) after heading period of main rice in 2008.

\begin{tabular}{lcccc}
\hline Different indexes & $\mathrm{R}^{2}$ & ARE & RMSE & $\mathrm{d}$ \\
\hline Biomass of green leaves & 0.732 & 2.370 & 0.390 & 0.948 \\
N accumulation of vegetation parts & 0.615 & 0.154 & 0.020 & 0.985 \\
N accumulation of green leaves & 0.728 & 4.979 & 0.011 & 0.961 \\
LAI & 0.740 & 0.975 & 0.602 & 0.976 \\
Mean of different indexes & 0.704 & 2.120 & 0.256 & 0.968 \\
\hline
\end{tabular}

LAI: Leaf area index; $\mathrm{R}^{2}$ : coefficients of determination; ARE: average relative error; RMSE: root mean square error; d: index of agreement. 
better, because the relation was good between measured and predicted values when $\mathrm{d}$ was around 1.00. This showed that models has good predictive and universality, and biomass of green leaves, $\mathrm{N}$ uptake of vegetative organs and green leaves and LAI in ratoon rice could be predicted by NDVI after heading in main rice.

\section{Development of regression models}

The regression models from the rice variety experiment in 2008 were (Figure 3 ) used to calculate predicted values with NDVI after heading of main rice in 2009 (Figure 4). The results showed that the predicted values of biomass, $\mathrm{N}$ uptake and LAI in ratoon rice were significantly different to measured values. However, biomass, LAI, and $\mathrm{N}$ uptake measured was related to the NDVI after heading of main rice from the rice variety experiment in 2009 (Table 4). It also showed and proved that there were exponential and positive correlation significantly $(\mathrm{p}<0.05)$ between biomass and $\mathrm{N}$ uptake and LAI in ratoon rice and NDVI after heading of main rice than before heading. These $\mathrm{R}^{2}$ were about $0.304-0.519$. Therefore, these regression models from the rice variety experiment in 2008 were different obviously in 2009. Maybe this was affected by environment factors such as temperature, radiation and $\mathrm{CO}_{2}$. It suggested that egression models were not perfect,
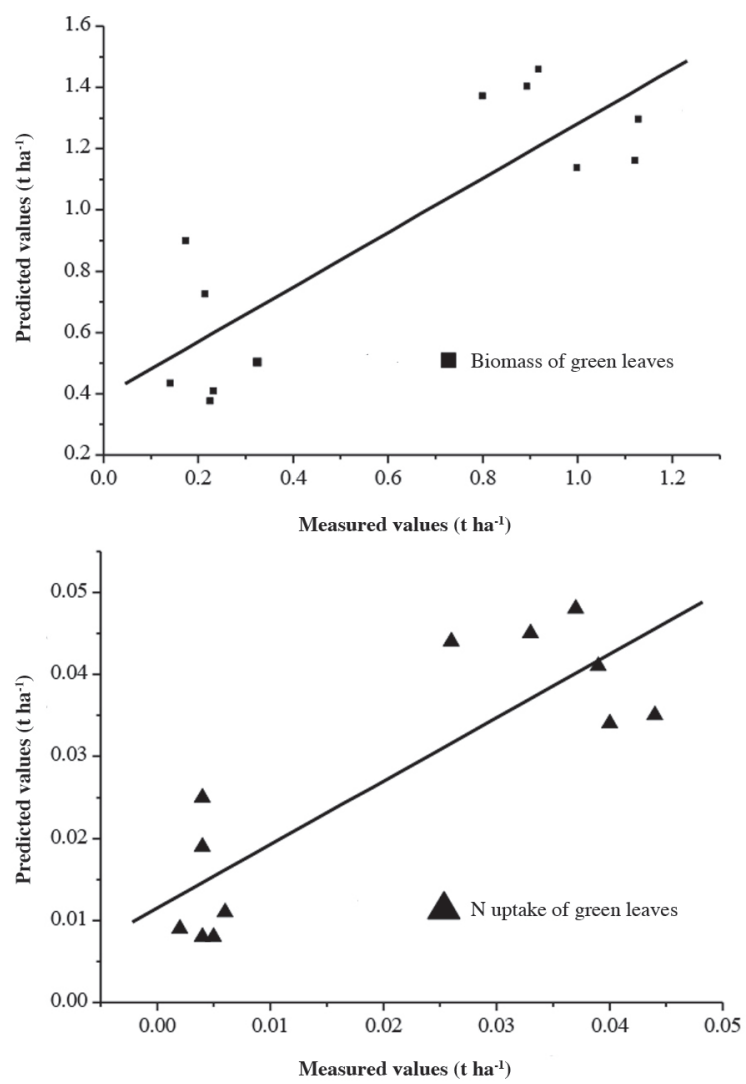

Table 4. The exponential regression of normalized difference vegetation index (NDVI) (X) after heading of main rice to the physiological indexes $(Y)$ after heading of ratoon rice from the rice variety experiment in 2009.

\begin{tabular}{|c|c|c|c|}
\hline $\begin{array}{l}\text { NDVI of main } \\
\text { rice }\end{array}$ & $\begin{array}{l}\text { Different indexes of } \\
\text { ratoon rice }\end{array}$ & $\begin{array}{l}\text { Regression } \\
\text { equation }\end{array}$ & $\begin{array}{c}\text { Correlation } \\
\text { coefficient } \\
\quad\left(R^{2}\right)\end{array}$ \\
\hline \multirow[t]{5}{*}{ After heading } & $\begin{array}{l}\text { Biomass of green leaves, } \\
\text { stem and panicle }\end{array}$ & $\mathrm{y}=13.392 \mathrm{e}^{-0.9339 x}$ & 0.0985 \\
\hline & Biomass of green leaves & $\mathrm{y}=0.0912 \mathrm{e}^{4.5742 \mathrm{x}}$ & $0.3346^{*}$ \\
\hline & $\begin{array}{l}\mathrm{N} \text { uptake of green leaves, } \\
\text { stem and panicle }\end{array}$ & $\mathrm{y}=0.0182 \mathrm{e}^{3.4129 \mathrm{x}}$ & $0.304^{*}$ \\
\hline & $\mathrm{N}$ uptake of green leaves & $y=7 E-06 e^{15.862 x}$ & $0.5199^{*}$ \\
\hline & LAI & $y=0.0087 e^{8.3717 x}$ & $0.478^{*}$ \\
\hline
\end{tabular}

LAI: Leaf area index.

and need to be improved with adding more parameters about spectral characteristic of main and ratoon rice.

\section{DISCUSSION}

The axillary buds began to germinate when $\mathrm{N}$ fertilizer for bud development was applied after heading of main rice; therefore, the excess nutrients were transported to axillary buds while nutrient of $\mathrm{N}$ and $\mathrm{C}$ meet to grain of main rice (Yi et al., 2009b). In our study, there was linear correlation between the grain yield of main and ratoon rice (Figures 1 and 2). This showed that ratoon rice growth
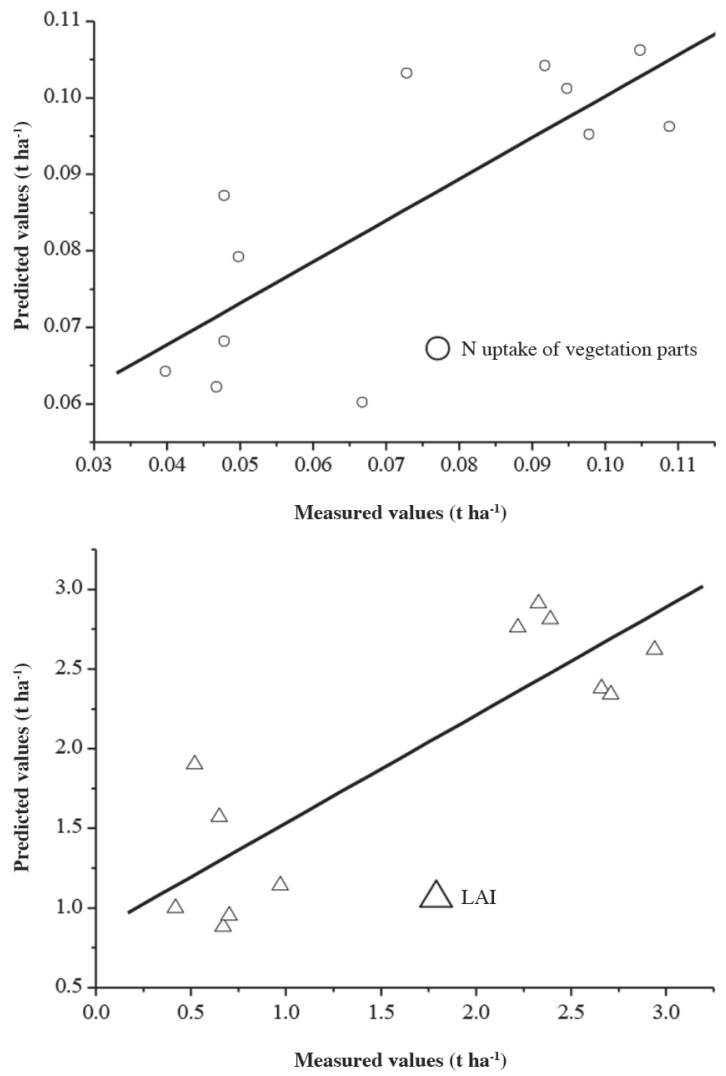

LAI: Leaf area index.

Figure 3. Relationships between the measured and predicted values of different indices of ratoon rice to normalized difference vegetation index (NDVI) after heading in main rice. 

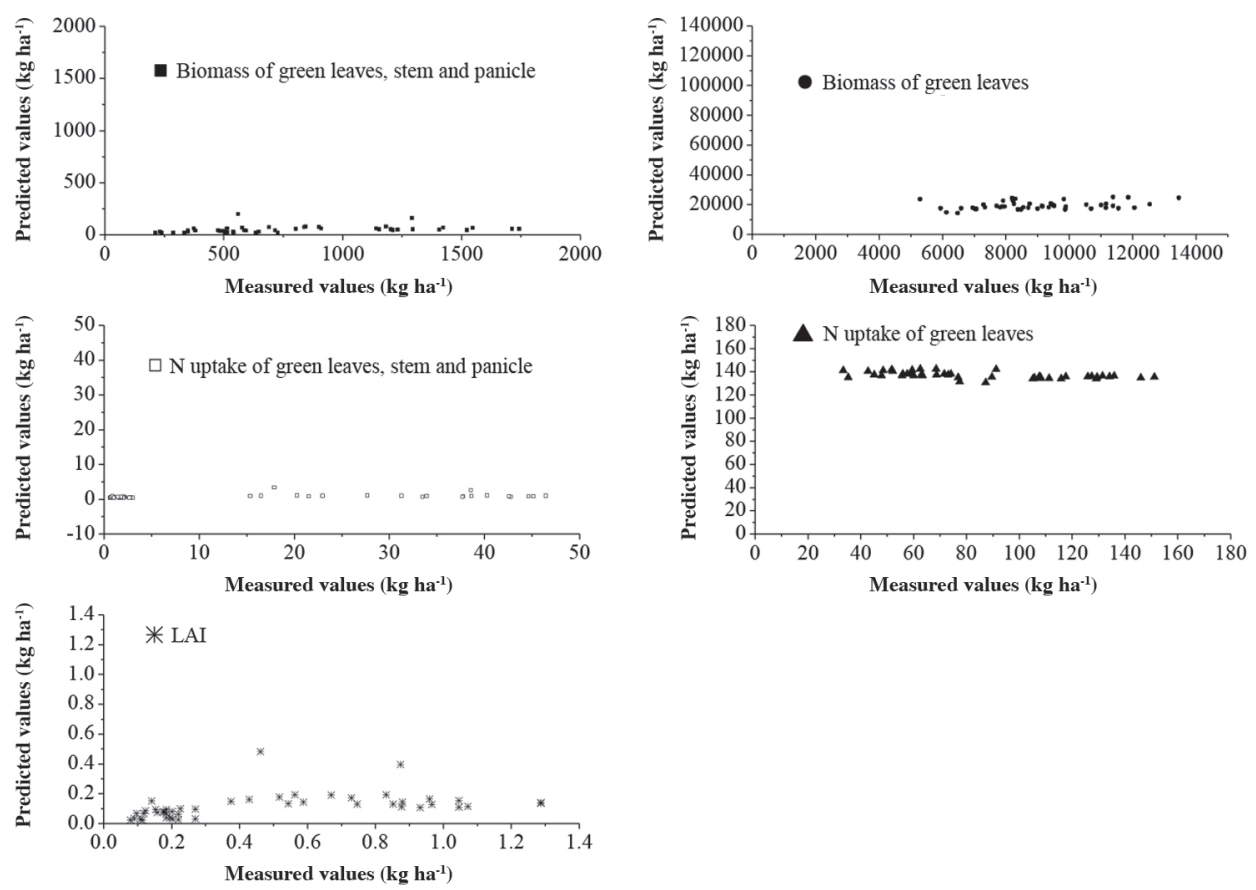

LAI: Leaf area index.

Figure 4. Relationships between measured and predicted values of different indices of ratoon rice to normalized difference vegetation index (NDVI) after heading of main rice from the rice variety experiment in 2009.

depends on main rice growth, because ratoon rice began to grow and develop in stubble of main rice when main rice was harvested. Many papers proved that the after heading stage of main rice is the critical stages for growth of ratoon rice (Xu et al., 2010). Liu et al. (2007) found that about $52 \%-70 \%$ assimilation production stored in stubble was distributed in ratoon rice, and most of them were distributed in the upper second and third nodes of ratoon rice. $\mathrm{Xu}$ et al. (2010) suggested appropriate amount of $\mathrm{N}$ application for bud development would be needed in 10$15 \mathrm{~d}$ after heading of main rice.

In rice cropping system, plant $\mathrm{N}$ accumulation could be estimated by GreenSeeker optical sensor (Xue et al., 2014; Ali et al., 2015). And NDVI had been used in N fertilizer management in many sites (Bajwa et al., 2010; Bijay-Singh et al., 2012; Yao et al., 2012; Bijay-Singh et al., 2015). There was an exponential and positive significant correlation $(\mathrm{p}<0.05)$ between NDVI and biomass and $\mathrm{N}$ uptake of green leaves and LAI before and after heading of main rice (Table 1). Our study suggested that biomass, $\mathrm{N}$ uptake, and LAI in rice could be better reflected by NDVI in this period. The correlation of NDVI with physiological parameters in main rice is direct and diagnostic. The result was agreed by many researchers (Casanova et al., 1998; Kimura et al., 2004; Zhu et al., 2008). The plant nutrients after heading in main rice were prepared for the growing of ratoon rice, besides some nutrients used by the grain (Nakano and Morita, 2007; 2008; Harrell et al., 2009). There was a linear correlation between the grain yield of main and ratoon rice (Figures 1 and 2). So, there was exponential and positive correlation between biomass and $\mathrm{N}$ uptake and LAI in ratoon rice and NDVI after heading in main rice (Table 2). Therefore, our study suggested NDVI after heading in main rice could be used to diagnose the biomass, $\mathrm{N}$ uptake of green leaves and LAI, comparing with other indexes in ratoon rice. However, these regression models from the rice variety experiment in 2009 were different obviously in 2008, and maybe it was affected by temperature, radiation and $\mathrm{CO}_{2}$ because the experimental site which was in valley of Fujian Province and was very close to the Pacific ocean. It suggested that regression models were not perfect because NDVI is one kind of vegetation indices and do not fully reflect the growing information of rice. So, regression models between biomass and $\mathrm{N}$ uptake and LAI in ratoon rice and NDVI after heading in main rice need to be improved with adding more parameters about spectral characteristic of main and ratoon rice.

\section{CONCLUSIONS}

There was exponential and positive significant correlation between biomass and $\mathrm{N}$ uptake and leaf area index of ratoon rice and normalized difference vegetation index (NDVI) after heading of main rice. These results indicated that NDVI values after heading of main rice can better reflect changes of physiological indexes in ratoon rice. However, these regression models need to be further verified before it would be applied in ratoon rice. 


\section{ACKNOWLEDGEMENTS}

This research was supported by Special Fund for AgroScientific Research in the Public Interest of China (200903002). It was also supported by the National Basic Research Program of China (973 Program) (2011CB100501-S06) and Jiangxi Science and Technology Support plan (20141BBF60050).

\section{LITERATURE CITED}

Ali, A.M., H.S. Thind, Varinderpal-Singh, Bijay-Singh. 2015. A framework for refining nitrogen management in dry directseeded rice using GreenSeeker ${ }^{\mathrm{TM}}$ optical sensor. Computers and Electronics in Agriculture 110:114-120.

Bajwa S.G., A.R. Mishra, and R.J. Norman. 2010. Canopy reflectance response to plant nitrogen accumulation in rice. Precision Agriculture 11:488-506.

Bijay-Singh, Varinderpal-Singh, Jaspreet Purba, R.K. Sharma, M.L. Jat, Yadvinder-Singh, et al. 2015. Site-specific fertilizer nitrogen management in irrigated transplanted rice (Oryza sativa) using an optical sensor. Precision Agriculture 16:455-475.

Bijay-Singh, Varinderpal-Singh, Yadvinder-Singh, H.S. Thind, Ajay Kumar, R.K. Gupta, et al. 2012. Fixed-time adjustable dose sitespecific fertilizer nitrogen management in transplanted irrigated rice (Oryza sativa L.) in South Asia. Field Crops Research 126:63-69.

Casanova, D., G.F. Epema, and J. Goudriaan. 1998. Monitoring rice reflectance at field level for estimating biomass and LAI. Field Crops Research 55:83-92.

Chen, H.F., R.Y. Lin, Y.Y. Liang, L.D. Zheng, K.J. Liang, and W.X. Lin. 2008. Dry matter accumulation and transportation in first rice crop of early rice-ratoon rice under different cultivation pattern. Chinese Journal of Eco-Agriculture 16(1):129-133 (in Chinese with English abstract).

Das, D.K., K.K. Mishra, and N. Kalra. 1993. Assessing growth and yield of wheat using remotely-sensed canopy temperature and spectral indices. International Journal of Remote Sensing 94:3081-3092.

Gnyp, M.L., Y.X. Miao, F. Yuan, S.L. Ustin, K. Yu, Y.K. Yao, et al. 2014. Hyperspectral canopy sensing of paddy rice aboveground biomass at different growth stages. Field Crops Research 155:42-55.

Guo, W.T. 1993. The studies on the ratoon rice development and history in China. Agricultural History of China 12(4):1-6 (in Chinese with English abstract).

Guo, J.H., X. Wang, Z.J. Meng, C.J. Zhao, Z.R. Yu, and L.P. Chen. 2008. The study on diagnosing nitrogen nutrition status of corn using Greenseeker and SPAD meter. Plant Nutrition and Fertilizer Science 14(1):43-47 (in Chinese with English abstract).

Harrell, D.L, J.A. Bond, and S. Blanche. 2009. Evaluation of maincrop stubble height on ratoon rice growth and development. Field Crops Research 114:396-403.

Inman, D., R. Khosla, R.M. Reich, and D.G. Westfall. 2007. Active remote sensing and grain yield in irrigated maize. Precision Agriculture 8:241-252.

IUSS Working Group WRB. 2014. World reference base for soil resources 2014. International soil classification system for naming soils and creating legends for soil maps. World Soil Resources Reports nr 106. 191 p. FAO, Rome, Italy.

Jiang, Z.W., W.W. Lin, Y.Z. Li, C.Y. Zhuo, and H.A. Xie. 2003. Effects of nitrogen fertilizer rates on uptake and distribution of nitrogen in ratoon rice. Fujian Journal of Agricultural Sciences 18(1):50-55 (in Chinese with English abstract).

Jiang, Z.W., W.X. Lin, Y.Z. Li, C.Y. Zhuo, H.J. Yang, and H.A. Xie. 2005. Effects of nitrogen fertilizer rates on some physiological characteristics of ratoon rice. Fujian Journal of Agricultural Sciences 20:168-171 (in Chinese with English abstract).
Kimura, R., S. Okada, H. Miura, and M. Kamichik. 2004 Relationships among the leaf area index, moisture availability, and spectral reflectance in an upland rice field. Agricultural Water Management 69:83-100.

Li, F., M.L. Gnyp, L.L. Jia, Y.X. Miao, Z.H. Yu, and W. Koppe. 2008. Estimating $\mathrm{N}$ status of winter wheat using a handheld spectrometer in the North China Plain. Field Crops Research 106:77-85.

Lin, R.Y., H.F. Chen, J.H. Deng, Y.Y. Liang, K.J. Liang, and W.X. Lin. 2007. Analysis on energy accumulation and calorific value of early-season rice and its ratooning rice under different cultivation models. Acta Agronomica Sinica 33:1794-1801 (in Chinese with English abstract).

Lin, W.X., H.F. Chen, Z.X. Zhang, J.H. Xu, N.M. Tu, C.X. Fang, et al. 2015. Research and prospect on physio-ecological properties of ratoon rice yield formation and its key cultivation technology. Chinese Journal of Eco-Agriculture 23:392-401 (in Chinese with English abstract).

Liu, A.Z., D.S. Zou, N.M. Tu, W.X. Zhou, and Y.X. Liang. 2007. Relationship between distribution of photosynthesis production of flag leaf of main crop and yield of rationing rice. Guangdong Journal of Agricultural Sciences 7:29-32 (in Chinese with English abstract).

Ma, B.L, L.M. Dwyer, C. Costa, E.R. Cober, and M.J. Morrison. 2001. Early prediction of soybean yield from canopy reflectance measurements. Agronomy Journal 93:1227-1234.

Nakano, H., and S. Morita. 2007. Effects of twice harvesting on total dry matter yield of rice. Field Crops Research 101:269-275.

Nakano, H., and S. Morita. 2008. Effects of time of first harvest, total amount of nitrogen, and nitrogen application method on total dry matter yield in twice harvesting of rice. Field Crops Research 105:40-47.

Nakano, H., S. Morita, I. Hattori, and K. Sato. 2008. Effects of planting time and cultivar on dry matter yield and estimated total digestible nutrient content of forage rice in southwestern Japan. Field Crops Research 105:116-123.

Raun, W.R., J.B. Soile, G.V. Johnson, M.L. Stone, E.V. Lukina, and W.E. Thomason. 2001. In-season prediction of potential grain yield in winter wheat using canopy reflectance. Agronomy Journal 93:131-138.

Wang, X.Z., J.F. Huang, Y.M. Li, and R.C. Wang. 2003. Correlation between chemical contents of leaves and characteristic variables of hyperspectra on rice field. Transactions of the Chinese Society of Agricultural Engineering 19:144-148 (in Chinese with English abstract).

Xu F.X., H. Xiong, L. Zhang, Y.C. Zhu, P. Jiang, X.Y. Guo, et al. 2015. Progress in research of yield formation of ratooning rice and its high-yielding key regulation technologies. Scientia Agricultura Sinica 48:1702-1717 (in Chinese with English abstract).

Xu, F.X., H. Xiong, Y.C. Zhu, and L. Zhang. 2008. Effect of the amount of $\mathrm{N}$ application for bud development on the rationing ability and in association with ratio of source to sink in mid-season hybrid rice. Southwest China Journal of Agricultural Sciences 21:688-694 (in Chinese with English abstract).

Xu, F.X., H. Xiong, Y.C. Zhu, L. Zhang, X.Y. Guo, and M. Liu. 2010. Effects of the time of $\mathrm{N}$ application for bud development on the ratooning ability of mid-season rice hybrids with different source-sink structure. Hybrid Rice 25(3):57-63 (in Chinese with English abstract).

Xue, L.H., G.H. Li, X. Qin, L.Z. Yang, and H.L. Zhang. 2014. Topdressing nitrogen recommendation for early rice with an active sensor in south China. Precision Agriculture 15(1):95-110.

Yao, Y.K., Y.X. Miao, S.Y. Huang, L. Gao, X.B. Ma, G.M. Zhao, et al. 2012. Active canopy sensor-based precision $\mathrm{N}$ management strategy for rice. Agronomy for Sustainable Development 32:925-933.

Yi, Z.X., N.M. Tu, P. Wang, and P.P. Chen. 2005. Ratooning properties of axillary buds of two-line hybrid rice in vivo and in vitro. Acta Agronomica Sinica 31:330-336 (in Chinese with English abstract). 
Yi, Z.X., W.X. Zhou, P. Qin, and N.M. Tu. 2009a. Differences in characteristics of source, sink and flow between ratooning rice and its same-term heading main-Crop rice. Acta Agronomica Sinica 35(1):140-148 (in Chinese with English abstract).

Yi, Z.X., W.X Zhou, and N.M. Tu. 2009b. Effects of stubble height of the main crop on source-sink characteristics and assimilates transportation in ratooning rice. Chinese Journal of Rice Science 23:509-516 (in Chinese with English abstract).

Zhang, G.L., N.M. Tu, J.H. Yuan, P. Liu, and S.T. Zhang. 2005. Effects of sowing stage on the sprouting of axillary bud and yield of ratooning rice. Journal of Hunan Agricultural University (Natural Sciences) 31:229-232 (in Chinese with English abstract).
Zheng, J.S., W. Lin, X.Y. Zhuo, X.J. Fang, and W.X. Lin. 2004. The correlation of dry biomass and activity of ratoon system with grain yield in ratoon rice. Chinese Journal of Eco-Agriculture 12(4):106-109 (in Chinese with English abstract).

Zhu, Y., X. Yao, Y.C. Tian, X.J. Liu, and W.X. Cao. 2008. Analysis of common canopy vegetation indices for indicating leaf nitrogen accumulations in wheat and rice. International Journal of Applied Earth Observation and Geoinformation 10:1-10. 